\title{
Ruminate on the Path Choice of Carbon Finance Development Under the Background of Low Carbon Economy
}

\author{
Tong Wang ${ }^{1, *}$ \\ ${ }^{1}$ Dongbei University of Finance and Economics, Surrey International Institute, Editorial Department, 116025 Dalian, China
}

\begin{abstract}
Low-carbon economy is one of the main trends of economic development at this stage, which emphasizes low energy consumption, low pollution, low emissions and high efficiency and effectiveness. The development of low-carbon economy pays more and more attention to the control of greenhouse gas emissions, so in practice, the construction and utilization of economic development model based on greenhouse gas emission control objectives has outstanding practical value. Carbon finance is a financial model that can effectively control greenhouse gas emissions based on the general background of low-carbon economy, and its influence is expanding in the process of worldwide low-carbon economic development. It is of outstanding practical significance to emphasize the choice of carbon finance development path in the context of low-carbon economy and to realize the standardization and specialization of carbon finance development. The article analyzes and discusses the path choice of carbon finance development under the background of low carbon economy, aiming to provide guidance and help for practical work.
\end{abstract}

\section{Introduction}

Low carbon and environmental protection are two concepts that are widely mentioned in current social and economic development practices. On the one hand, low carbon and environmental protection have outstanding social and ecological benefits, through the control of carbon emissions and the strengthening of environmental protection, the world's environmental problems will be effectively alleviated, such as global warming problems will slow down the process with the weakening of greenhouse gas emissions. On the other hand, low carbon and environmental protection have outstanding economic benefits. The outstanding value of energy resources is reflected in the creation of economic value, manufacturing the same economic value using less energy, and by the same token, creating greater economic value with the same energy, which will result in significant improvements in the quality of social and economic development, etc. The development of carbon finance is significant to the progress of low carbon economy, so it is of outstanding practical significance to emphasize the development path of carbon finance based on low carbon economy.

\section{Overview of carbon finance}

To clarify the development path and options of carbon finance in a low-carbon economy, it is necessary to grasp the definition of carbon finance. According to the information available, carbon finance refers to the use of financial capital to drive the improvement of environmental rights and interests, supported by laws and regulations, and the use of financial instruments and methods to trade or circulate carbon financial products and their derivatives on a market-based platform, so as to ultimately achieve the purpose of low-carbon development, green development and sustainable development [1]. From the analysis of the specific definition of carbon finance, its fundamental characteristic is to serve the environment, that is to say, the ultimate purpose of the development of carbon finance is to achieve the control of social and ecological environment, so as to provide a better natural ecological environment for economic development and social construction. The following diagram shows the basic framework of carbon finance.

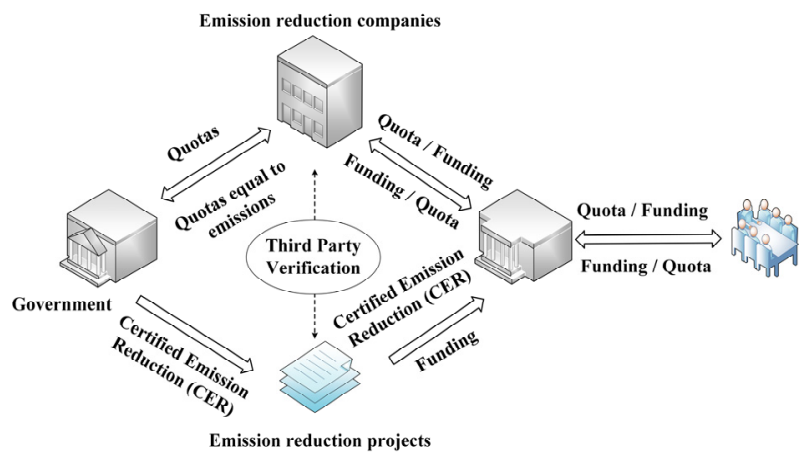

Fig.1 The basic framework of carbon finance.

*Corresponding author: WT0806@outlook.com 


\section{Problems of carbon finance development under low carbon economy}

The development history of carbon finance can be traced back to two very important international conventions, namely the United Nations Framework Convention on Climate Change (UNFCCC) and the Kyoto Protocol, the former of which entered into force in March 1994 and the latter of which came into effect in 1997 [2]. To date, the development of carbon finance has been nearly 30 years of history, and in these nearly 30 years of development, carbon finance has provided a lot of assistance to the development of low carbon economy. Summarizing the development of carbon finance in China, we found that there are several significant problems in it, and the following is the summary of the problems, as shown in Fig.2.

\subsection{Policy risks cause constraints}

In the practice of carbon finance development in China, the policy risk has formed a constraint to the development of carbon finance. The development of carbon finance depends on policy, so policy issues will directly lead to carbon finance development problems. In the practice of carbon finance development, its specialization, standardization and low risk development are significantly related to the policy. Since the development system of carbon finance in China is not perfect and the corresponding theoretical support is very weak, the government is unable to achieve the dispersion of risks or only reduce them when making policies, which leads to the development of carbon finance itself is limited. The restricted development of carbon finance affects the further development of low carbon economy, so in the long run, it is difficult to form a virtuous circle between low carbon economy and carbon finance.

\subsection{Low credit support from banks}

The development of carbon finance needs financial support, so in the process of carbon finance development, banks and other credit institutions need to provide financial support for carbon finance, but according to the summary of current data, because China's low-carbon awareness is still relatively weak, so the research and implementation of the development strategy of lowcarbon economy is not in place [3]. Society also does not have an accurate perception of the development potential of the low-carbon economy, which leads to the banks themselves not realizing the huge benefits of the lowcarbon economy. Because of the banks' own cognitive deficiencies, their rejection of carbon finance is relatively strong, so the credit support they can provide is relatively low. Furthermore, policy reasons are also an important factor in the low credit support from banks.

\subsection{Single financing mechanism}

The third significant problem in the development of carbon finance is that the financing mechanism is relatively single, and the result of this situation is that the effect of carbon finance financing is not satisfactory, specifically: the financing channel of carbon finance is narrow and the scale of carbon finance is relatively small. Because of the difficulties in financing, the overall development of carbon finance has been limited. In short, the single financing mechanism brings inconvenience to the development of carbon finance, so it is necessary to solve this problem in practice.

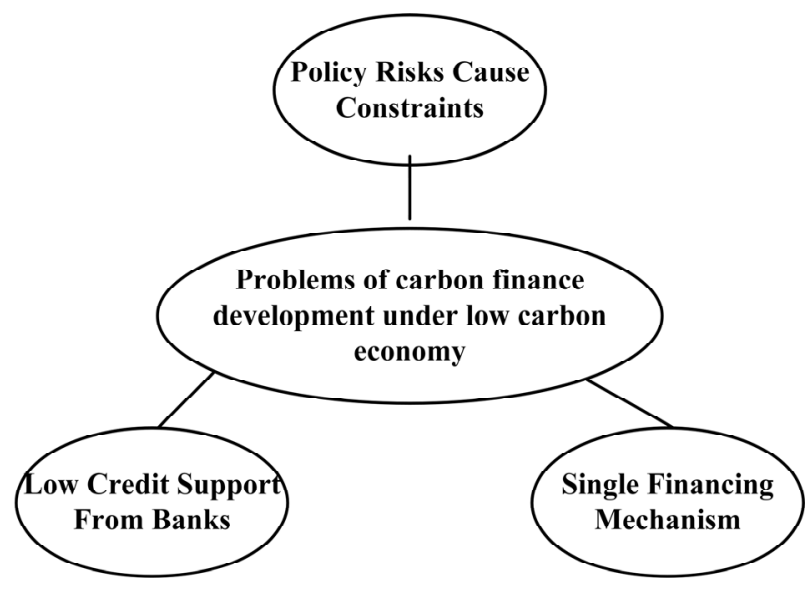

Fig.2 Problems of carbon finance development under low carbon economy

\section{The path selection strategy of carbon finance development under the background low carbon economy}

The professional and standardized development of carbon finance in the context of low-carbon economy requires scientific selection of development paths, so that the development results of carbon finance will be more prominent and its effectiveness and value effects will be significantly enhanced. Based on the summary of relevant research at home and abroad, the development of carbon finance in low-carbon economy needs to be carried out from the following three aspects.

\subsection{Building a carbon finance platform under the guidance of the government}

Based on the professional, standardized and unified development of carbon finance, it is very important to build a carbon finance platform under the guidance of the government, and cultivate the carbon trading market system through the construction of carbon finance platform, so that the professional and standardized performance of carbon finance development will be more prominent. In terms of the specific construction of the carbon finance platform, there are two main tasks: 1) actively analyze and summarize the international carbon trading mechanism, and on the basis of the mechanism understanding of China's actual situation, the establishment of a carbon finance exchange belonging to 
China, so that the price discovery function of the market can be strengthened [4]. In general, the construction of the platform has a very important role in the transformation of China's economic development, and the construction of the carbon finance platform provides a quasi-financial platform for the development of a lowcarbon economy, which can provide financing services for low-carbon technologies of enterprises in the lowcarbon field. 2) The establishment of an intermediary organization for carbon emissions trading through the strengthening of publicity and promotion. A comprehensive analysis of the development practice of carbon finance shows that it has two distinctive features, one of which is its strong policy and the other is its wide scope. Therefore, in practice, it is necessary to let the community have a more comprehensive understanding of carbon finance, such as the value of carbon finance, its operation mode and trading rules. Through the awareness of carbon finance, enterprises and individuals will have a better understanding of low carbon economy, and the awareness of low carbon will be more significant, and the huge business opportunities contained in carbon finance will be explored when the awareness is generally enhanced. Based on the local need to build a carbon finance intermediary organization, fully apply their own advantages, such as the advantages of information resources, customer resources, etc. to achieve the carbon finance project development process of the audit cost and audit time reduction, which is significant for the relevant work of risk control. In short, no matter it is the construction of unified platform or intermediary organization, the value in the practice of carbon finance development is self-evident under the guidance of the government to ensure the standardization and professionalism of the organization and platform.

\subsection{Promoting low carbon theory and credit product innovation}

The analysis of carbon finance development at this stage shows that the professionalism and standardization of carbon finance development are significantly related to theories, so in practice, it is necessary to actively carry out theoretical innovation based on the general background of low-carbon economic development and the development needs of carbon finance. In the overall analysis, carbon finance is very extensive, and it requires not only financial knowledge, but also expertise in carbon technology and project evaluation and management. Therefore, in the process of carbon finance development, it is necessary to promote theoretical innovation based on the actual situation, so that the development of low-carbon economy and carbon finance is supported and guided by more professional theories. The innovation and development of low carbon economy theory and professional team building are significantly related, so it is necessary to actively carry out professional team building based on the general background of low carbon economy and continuously improve the professionalism of practitioners, so that the basis of low carbon theory innovation will be significantly improved and the actual effect of corresponding work and theory building will be significantly strengthened.

Based on the practical discussion, it is known that the development of carbon finance should not only emphasize theoretical innovation, but also pay more attention to product innovation, therefore, for the lowcarbon economy, credit products should be developed so that the professionalism and diversification of the products themselves can be brought into play, so that the overall progress effect of carbon finance will be more significant [5]. In general, the development of lowcarbon economy needs financial innovation and financial instruments to achieve the diversification and conversion of investment risks. Based on this, in the development practice, China can actively learn from the world's financial institutions with rich experience to achieve financial product development that is compatible with the low-carbon economy, such as the development of carbon fund financial products, the introduction of private equity funds, etc. The development of these businesses and products will make the overall performance of the carbon financial market more professional. In addition, financial derivatives such as carbon swap trading and carbon securities can also be developed and utilized in depth, and the further development and application of these products will inevitably lead to the construction of low-carbon projects and the effective development of carbon finance.

\subsection{Strengthening low-carbon incentives and policy implementation mechanism}

The development of carbon finance in the context of low-carbon economy also needs to strengthen the lowcarbon economic incentives and policy implementation mechanism. The specific development of low-carbon economy is inseparable from policies, and is also significantly related to the low-carbon awareness of people and enterprises. Therefore, to promote the development of low-carbon economy and carbon finance, it is essential to emphasize the stimulation of enterprises and people. The government, as an important promoter and regulator of low-carbon economy and carbon finance, can stimulate and control the development of low-carbon economy and carbon finance in terms of policies [6]. In terms of incentive, mainly the government actively formulates strategies that help the development of low-carbon economy and carbon finance, realizes policy support for the development of lowcarbon economy of enterprises, and makes the development of low-carbon economy of enterprises solve the problems through policy help, so that the development of enterprises can be stimulated. Of course, in order to ensure the development effect of low-carbon economy of enterprises, the government needs to build corresponding control institutions, and implement the summary and evaluation of low-carbon economy development through professional work content and responsibility system to realize the professional guidance of low-carbon economy, so that the development 
practice effect of low-carbon economy will be more prominent [7]. Based on the development of low-carbon economy to do the summary and evaluation of the development of carbon finance, the same use of incentives to stimulate, so that the development of carbon finance will also be more professional performance [8].

\section{Conclusion}

In summary, the impact of low-carbon economic development on social life and economic development is significant, so in the current practice of social development, actively emphasizing low-carbon economy and guiding low-carbon economy through diversified means is significant in reality. The article analyzes the development practice of carbon finance in low carbon economy and discusses the choice of carbon finance development path, with the aim of providing help and guidance for the overall development progress of carbon finance.

\section{References}

1. X. Huang, W. Zhang and H. Ding, Research on Chinese low-carbon economy mode and system. 2011 International Conference on Electronics, Communications and Control (ICECC), Ningbo, China, 2011, pp. 3881-3884.

2. Ming Zhang and Xiang Huang, Research on the concept system and construction pattern of low carbon tourism based on low carbon economy. 2011 International Conference on Remote Sensing,
Environment and Transportation Engineering, Nanjing, China, 2011, pp. 3403-3409.

3. Y. Wei-yi and Y. Bo, Promotion Path of Lowcarbon Economy Based on Low-carbon Chain. 2011 International Conference on Information Management, Innovation Management and Industrial Engineering, Shenzhen, China, 2011, pp. 7-10.

4. J. Cheng, G. Zeng and T. Fang, The Origin and Connotation of Low Carbon City: A Conceptual Framework. 2012 Fifth International Joint Conference on Computational Sciences and Optimization, Harbin, China, 2012, pp. 706-709.

5. W. Wei-Yu and Y. Nian, Low Carbon Economy Evaluation Index System and Development Evaluation of Hebei. 2013 Sixth International Conference on Business Intelligence and Financial Engineering, Hangzhou, China, 2013, pp. 572-575.

6. S. Lu, Y. Wu, S. Lou and X. Yin, A Model for Optimizing Spinning Reserve Requirement of Power System Under Low-Carbon Economy. IEEE Transactions on Sustainable Energy, vol. 5, no. 4, pp. 1048-1055, Oct. 2014.

7. Xilin Shen and Yanyan Wang, The path of the development of low-carbon economy in Nanchong. 2011 Second International Conference on Mechanic Automation and Control Engineering, Inner Mongolia, China, 2011, pp. 7023-7026.

8. Z. Li and L. Zhang, Carbon Finance Development Status and Development Strategy of Our Country under Low-Carbon Economy. 2011 Fourth International Joint Conference on Computational Sciences and Optimization, Kunming and Lijiang City, China, 2011, pp. 1150-1154. 